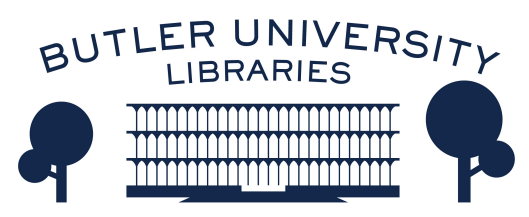

Journal of Hindu-Christian Studies

Volume 12

Article 5

January 1999

\title{
"Deo, Non Fortuna": Christian, Time, and Technology
}

David J. Hawkin

Follow this and additional works at: https://digitalcommons.butler.edu/jhcs

Part of the Religion Commons

\section{Recommended Citation}

Hawkin, David J. (1999) "'Deo, Non Fortuna": Christian, Time, and Technology," Journal of Hindu-Christian Studies: Vol. 12, Article 5.

Available at: https://doi.org/10.7825/2164-6279.1203

The Journal of Hindu-Christian Studies is a publication of the Society for Hindu-Christian Studies. The digital version is made available by Digital Commons @ Butler University. For questions about the Journal or the Society, please contact cbauman@butler.edu. For more information about Digital Commons @ Butler University, please contact digitalscholarship@butler.edu. 


\title{
Deo, Non Fortuna: Christianity, Time, and Technology
}

\author{
David J. Hawkin \\ Department of Religious Studies \\ Memorial University of Newfoundland
}

\section{Introduction}

It is commonly asserted that Christianity is the historical religion par excellence. ${ }^{1}$ Its view of time is frequently contrasted with that of Eastern philosophies and religions. It is said to have a "realist" and a "positive" view of time, while religions such as Hinduism are said to have a "pessimistic" view of time in which temporal existence is seen to be mere illusion. ${ }^{2}$. These generalizations are often schematized into analogies about "linear" time and "cyclical" time and influential conclusions about Eastern and Western culture are often drawn from such contrasts. One very prevalent argument which emerges from such discourse is that Christianity is ultimately responsible for the rise of science and technology in the Western world, as it helped to create a culture in which they could flourish. There are literally dozens of scholars ${ }^{3}$ who argue that Christianity, by emphasizing linear time and ultimate fulfilment, provided the necessary cultural preconditions for technological novelty and scientific progress. It is a significant argument, for it goes to the heart of the question of why Western society is the way it is. In what follows, therefore, I will examine both the argument that Christianity espouses a linear view of time and the argument that there is a direct link between this view and the rise of science and technology.

Time in the Self-Understanding of the Early Christians

The argument that Christianity is a historical religion is rooted in the fundamental assertion that Jesus the Christ was an actual historical person born during the reign of Emperor Augustus. The Apostles' creed states that Jesus "suffered under Pontius Pilate". The salvation of humankind can thus be found in this particular event which occurred at a specific point in time. But there is even more to it than this, for pervasive throughout Christian theology is the idea that events throughout time are all part of a salvation history scheme in which God reveals his purposes for humankind. ${ }^{4}$

Yet simply to assert that Christianity has a linear view of time does not do justice to the intricacy of the origins of Christianity and the complex attitude to time which those origins generated. To gain a fuller understanding of the Christian attitude to time it is necessary, therefore, to examine the selfunderstanding of the early Christians.

Christianity began as a movement within Judaism and the early Christians thus presupposed a Judaic view of the world and humanity. In this view God is found within the limitations of the world of change and he reveals himself in history in events which are unique, particular, and unrepeatable. History is a sequence of events and is the arena of God's activity; events are thus endowed with value and purpose. But although Christianity began as a movement within Judaism it soon became imbued with the Greek spirit as it grew and flourished in its hellenistic environment. In the Greek thought which permeated this environment reality is perceived when, by rational 
contemplation, we go beyond the events of history. The goal is the apprehension of the unchanging absolutes that belong to the eternal order. ${ }^{5}$ In classical Judaism time is seen as history and events within history are seen as having value in revealing God's purposes. In classical Greek thought value is found in the unchanging absolutes beyond time - there is an order in the world and reason enables us to discern that order and to live by it. In Judaism, however, what one was to do with one's life was revealed in the events of history, and especially in the giving of the Torah. Thus in Greek thought our distinctive humanity lay in the rational apprehension of the cosmic order and our place in it, whereas in Judaism our distinctive humanity lay in the fact that we can choose: we can either obey or disobey the will of God. In Greek thought the emphasis was on "know thyself", whereas the Jew identified much more with the summons of Joshua: "choose ye this day" (Joshua 24:15; cf. I Kings 18:21).

The universes of discourse of Judaism and classical Greek thought are thus quite different. But as an original Jewish movement ${ }^{6}$ which flourished in a hellenistic environment, Christianity was exposed to both universes of discourse and incorporated into itself important elements from both views as it grew and developed. Christianity established itself in its hellenistic environment by focusing on emphases which were different from those found in its apocalyptic beginnings. Early apocalyptic Christianity focused on the end of time, when there would be a general resurrection and a judgment by Jesus who would return as the Son of Man to transform the earth (cf. Mark 9:1, 14:62; I Thess 4:13ff.). This is often referred to in spatial terminology as the horizontal view of salvation where salvation lies either in history or in the climax to history. Most of the hellenistic world did not think in these terms, but thought rather in terms of redemption from this world to a higher level of existence. This is often referred to as the vertical view of salvation in which two coexistent worlds are envisioned - one above and one below or, to put it another way, one heavenly and one earthly. Earthly existence is merely a shadow of the heavenly. Earthly existence is an imperfect, fallen existence and history is seen as "a prolongation of the meaningless"? Salvation comes when a redeemer figure comes to earth and frees humanity from earthly existence.

When early Christianity became transposed onto hellenistic soil, therefore, it underwent significant change and began to express itself in a discourse that was compatible with hellenistic thought. ${ }^{8}$ But the Judaic view of salvation was too firmly embedded in the tradition to be eradicated by these developments, and so early Christian self-understanding was a paradoxical mixture of the horizontal and vertical views of salvation. Nowhere is this paradoxical mixture seen more clearly than in the Gospel of John.

The Gospel of John is full of images which suggest a vertical view of salvation. There is a sphere of the spirit and a sphere of the flesh (3:6, 6:53); there is light and darkness, truth and falsehood, above and below. In the Gospel of John, Jesus is the Son of Man who has ascended and descended (3:13; cf. 6:62). He is from above, everyone else is from below (8:23). $\mathrm{He}$ alone is of heavenly origin (1:1ff; cf. 8:58). No one has ascended and seen the Father but the Son of Man alone who, being in the bosom of the Father, has descended to reveal him (1:18). He is, moreover, a stranger to this world $(17: 14,17: 16,18: 30)$, a world which is controlled by the Ruler of Darkness $(12: 31,14: 30)$, and in which humans are in bondage to $\sin (8: 31 \mathrm{ff}$.). The world is in some way intractable, in a fallen state, and resists the love of God. Thus Jesus prays for "his own" in chapter 17 but not for the world (17:9).

But this vertical view of salvation which is so prominent in the Gospel does not succeed in displacing the horizontal view. The opening verses in the Gospel begin with creation and speak in terms of God's decisive act in history. ${ }^{9}$ God gives his Son for the salvation of the world $(3: 16)$ and the world is created through him (1:3). God 
cares for the world, which he seeks to transform through his love (cf. 1:29). The Gospel speaks often of the "hour" of Jesus. This hour refers to Jesus' passion, death and resurrection. It is the climactic point of God's dealings with humankind. Moreover, history does not stop at this hour. There is more. God's activity in the world continues through the followers of Jesus. The Gospel presupposes a Christian mission (4:35-38; 20:21) and a continuing conflict with the world (17:20) leading to a final consummation (11:52, 10:16, 21:15-17).

Thus in the Gospel of John we have both the vertical and the horizontal views of salvation. This paradox can be seen most clearly in John chapter 5 where, in the space of five verses, both views are juxtaposed. John 5:24 says: "Very truly, I tell you, anyone who hears my word and believes him who sent me has eternal life, and does not come under judgment, but has passed from death to life" whereas 5:29 says: "[T] he hour is coming when all who are in their graves will hear his voice and will come out - those who have done good, to the resurrection of life, and those who have done evil, to the resurrection of condemnation". In 5:24 this life is transcended as it is clearly implied that this mortal realm has no value because the believer has passed from death to life. But in 5:29 our historical existence does have value because on the last day we will be judged on the basis of our actions in this life.

The Gospel of John is a fine example of the paradoxical nature of early Christian self-understanding with regard to time and history. The classical Greek understanding is juxtaposed in an uncompromising way with the Judaic view. This juxtaposition is found beyond the New Testament period, especially in the Alexandrian school in the thought of such as Origen. The deepest and most complex formulation of the Christian idea of time is found, however, in the thought of Augustine. ${ }^{10}$ In his famous discussion of time, in Confessions IX, Augustine seeks to demonstrate that God is eternal, but because he is the creator he initiates the temporal process and is found within it. ${ }^{11}$ The Christian idea of time cannot, then, be reduced to single categories such as "linear" or "vertical", for neither in the New Testament nor in subsequent eras is the Christian idea of time presented in such mutually exclusive categories. Nevertheless, as we have already noted, the argument that Christianity is ultimately responsible for creating an understanding of time which promotes the development of science and technology is very prevalent - indeed, it has become conventional wisdom. It is worth, therefore, looking at this argument, which Cameron Wybrow has aptly dubbed "the mastery hypothesis", 12 in greater detail.

\section{The Mastery Hypothesis}

The mastery hypothesis rests firmly upon the argument that Christianity has a distinctive, linear view of time. It is a view of time, the argument goes, which is derived from the Bible. Moreover, creation by God, as related in Genesis, not only ushers in the temporal order, it also separates the natural world from the object of faith, thus "disenchanting" nature. This, it is claimed, creates a "cultural prerequisite" for science and technology. Societies which are culturally dominated by a magical worldview will not embrace science and technology, which seek to manipulate nature, because "forests and streams, fields and rocks are experienced as the locus of deity". ${ }^{13}$

The first thing to note about this argument is that it does not imply a causal connection between a disenchanted worldview and the rise of technology. It merely states that technology could not have arisen had not the disenchantment of nature first taken place. Moreover, in the first place it is clearly an over-generalization to characterize non-Christian worldviews as "magical", and secondly, cultures which apparently do fall into this classification were not necessarily technologically inhibited. Ancient Egyptian culture was dominated by myth and magic yet the Egyptians were technologically advanced enough to build the pyramids!

This particular argument about 
Christian linear time is, then, suspect. But the mastery hypothesis has a second, more significant argument which, while related to the first, may be clearly differentiated from it. This argument says that the Bible attributes a special value to working within the sequence of events which we call "history". By emphasizing the value of history the Bible encourages us to change events and chart our own destiny. The technological and scientific enterprise is predicated on the idea that change is not only necessary and desirable, but possible. The advocates of the mastery hypothesis point out that if history is seen as the theatre of human response and the scene of unique and unrepeatable events, then an appropriate response is to try to influence the course of those events. But it is worth noting two points about the way this argument is presented. First, there is a difference between saying that the biblical worldview provides the cultural preconditions which permit the rise of science and technology and saying that the biblical worldview encourages the rise of science and technology. But the mastery writers slip almost imperceptibly from one point to the other. A fatalistic view of the world - a view which gives no value to our existence in the world - would inhibit the rise of science and technology and so, conversely, a view which stresses the value of acting in history does provide cultural preconditions for the innovative and creative activities of science and technology. But it is an inadmissible leap in the argument to say that such activities are encouraged by the biblical worldview. This extension of the argument cannot be supported by the evidence. ${ }^{14}$ Second, however, and more importantly, it is very noticeable that the mastery scholars base their arguments almost exclusively on the Old Testament/Hebrew Bible where, of course, they find what we have referred to as the horizontal view of salvation. Had they focused on the New Testament they would have had to come to a very different conclusion. For, as we have seen, in early Christian thinking the horizontal view and the vertical view are juxtaposed. To equate the Christian position with the horizontal view and set it over against the vertical one simply ignores this fact. Christianity does not have either a horizontal or a vertical view; it has both.

\section{Conclusion}

The argument that Christianity has a linear view of time which created the cultural prerequisites for the rise of science and technology is over-simplified. Christianity does not have an exclusively linear view of time: within the tradition linear and vertical views are held together in a dynamic tension. As Thorleif Boman has observed: "Eschatology and belief in the timeless Beyond are not two forms of the Christian hope that are mutually exclusive, but they are equally necessary thought-forms enjoying equal privileges and complementing one another."15 This may suggest that the technological worldview, which is underpinned by a progressive Hebraic view of time, will not be dominant indefinitely, for Christian history intimates that a view which focuses on a "timeless Beyond" is equally necessary to create a dynamism in which true spiritual discernment can take place. Moreover, the claim that the Christian view of time is "completely different" from that of Hinduism ${ }^{16}$ needs to be challenged. Whilst there certainly are significant differences, the contrast is perhaps not as absolute as first appears, given that Christianity does not, in fact, have a singular linear view of time. Thus pursuing a dialogue on time between Christianity and Hinduism may be more fruitful than conventional wisdom would suggest. Audiatur et altera pars.

\section{Notes}

1. S. G. F Brandon, History, Time and Deity: A Historical and Comparative Study of the Conception of Time in Religious Thought and Practice (Manchester: Manchester University Press, 1965), p. 148.

2. Cf. J. L. Russell, "Time in Christian Thought" in J. T. Fraser (ed.), The Voices of 
Time: A Cooperative Survey of Man's Views of Time as Expressed by the Sciences and by the Humanities (New York: George Braziller, 1966), p. 59.

3. See the extensive list of such scholars and their works in Cameron Wybrow, The Bible, Baconianism, and Mastery over Nature (New York: Peter Lang, 1991), pp. 212-215.

4. One of the best presentations of salvation history is found in the New Testament in the Gospel of Luke. See H. Conzelmann, The Theology of St Luke (New York: Harper and Row, 1961).

5. This is, for the sake of comparative argument, a schematic statement. Greek thought about time was very complex. There was general agreement that time was in some way cyclical, but beyond that there was no consensus. Heraclitus argued that the world was subject to change and time was, like the world, also subject to change and therefore real. Heraclitus thus proposed a dynamic, immanent view of time. This contrasted with the view of Parmenides who thought that change was illusory and time was therefore unreal. Plato shows the influence of both thinkers. He thought that there was change in the world, but the temporal world was to be differentiated from the non-temporal world - the world of the Ideal. The essence of things was eternal and unchanging. The world was an imperfect image of the Ideal, and time was a "moving image of eternity" (Timaeus, 37d). See Lawrence W. Fagg, The Becoming of Time: Integrating Physical and Religious Time (Atlanta: Scholars Press, 1995), pp. 15ff. In terms of the Hebraic view of time there have been a number of Jewish writers who have presented a more complex view of the matter than that which I have described. Vassilis Lambropoulos, The Rise of Eurocentrism: Anatomy of Interpretation (Princeton: Princeton University Press, 1993), acknowledges that "the present of the West has always been hopelessly caught between its Hellenic past and Hebraic future" (p. xi). He sees the significant turn in Western history in the Reformation and its "decree against referentiality, against heteronomy, against matters of the world" (ibid.). His book is not therefore an attempt to provide a "linear history" but rather a series of digressions on the aesthetic as an expression of autonomy. Yosef Hayim Yerushalmi, Zakhor: Jewish History and
Jewish Memory (Seattle \& London: University of Washington Press, 1982) deals with a paradox: that although Judaism throughout the ages has been absorbed with meaning in history, historiography itself has been unimportant. To put it another way: memory is central to the Jewish experience, but the transmission of this memory was not primarily seen as the job of the historians. Among Christian scholars who have written on the topic, one of the most significant is Brevard Childs who, in Myth and Reality in the Old Testament (London: SCM, 1960), argued that simply focusing on the events of Israel's history missed the point that "the reality with which the Old Testament is concerned is anchored to the totality of Israel. Reality is not found in historical happenings which impinge from above upon Israel and to which it subsequently adds subjective reflection. All such distinctions do not take seriously the fact that God has made himself known in the total experience of Israel" (p. 102). James Barr, Biblical Words for Time (London: SCM, 1962) cautions against overly simple contrasts between Greek and Hebrew thought. Bertil Albrektson, History and the Gods: An Essay on the Idea of Historical Events as Divine Manifestations in the Ancient Near East and Israel (Lund: CWK Gleerup, 1967), challenges the view that "religions of the Ancient Near East traced the divine powers in the recurring interplay of the forces of nature, whereas the Old Testament finds God revealed in the unrepeatable events in history" (p. 12).

6. I wish to stress that my argument here is about how Christianity began within Judaism. Both religions now have, of course, their own distinctive identities and self-understanding. Some scholars are disconcerted by the habit of referring to Judaism as the "parent faith" of Christianity, and would rather have Christianity and Judaism seen as sibling faiths. Cf. Michael Hilton, The Christian Effect on Jewish Life (London: SCM, 1994), p. 4: "It is indeed painful to discover that someone you had always thought of as your parent is in fact not a parent but a brother or sister. Both Jews and Christians have long supposed not simply that Judaism is an older religion than Christianity, but that everything Jewish therefore has to be older than every Christian custom. This model of the 
formation of the two faiths has had profound implications for the relationship between them."

7. R. E. Brown, The Gospel According to John (i-xii) (Garden City, New York: Doubleday, 1966), p. cxv.

8. See Dennis C. Duling and Norman Perrin, The New Testament: Proclamation and Parenesis, Myth, and History (Toronto: Harcourt Brace College Publishers, 1994), pp. 112-129.

9. See P. Lamarche, "The Prologue of John," in J. Ashton (ed.), The Interpretation of John (Philadelphia: Fortress Press, 1986), pp. 3652.

10. See Fagg, The Becoming of Time, p. 17, who says that Augustine's thought on time is "one of the most well-known and incisive discourses on the nature of time in Western literature".
11. See F. Callahan, Four Views of Time in Ancient Philosophy (Cambridge: C.U.P., 1948; M. E. Ravicz, "Time and Eternity" Thomist 22 (1959), pp. 542-554; W. B. Green, "St. Augustine on Time" Scottish Journal of Theology 18 (1965), pp. 148-163.

12. Wybrow, The Bible, Baconianism, and Mastery over Nature, p. 3.

13. Harvey Cox, "The Christian in a World of Technology" in Ian G. Barbour (ed.), Science and Religion (New York: Harper and Row, 1968), p. 262. Cox's article is a fine summary of the mastery hypothesis.

14. See Wybrow, The Bible, Baconianism, and Mastery over Nature, esp. pp. 101-159.

15. T. Boman, Hebrew Thought Compared with Greek (New York: W.W. Norton Inc., 1970), p. 163.

16. Brandon, History, Time and Deity, p. 3. 